"Now I understand: the question which you would have me consider is, not only bow a State, but bow a luxurious State is created ... If you wish also to see a State at fever heat ... The original healthy State is no longer sufficient. Now will the city have to fill and swell with a multitude of callings which are not required by any natural want." Republic, Book II.

\title{
LOSING OUR SPACE/MADĪNAH: FROM THE MADĪNAH OF REALITY TO A SIMULATION CITY
}

\author{
Ahmet Dăg \\ Bursa Uludă̆ University, Bursa-Turkey \\ ahmetdag@uludag.edu.tr \\ https://orcid.org/0000-0001-6173-9966
}

\begin{abstract}
Architecture or building a madīnah corresponds not only to constructing what is physical but also to building people and a community. Humans construct the madinah just as the madinahs build the people. Quarters (mahallahs) or madinahs present not only physical structures but also have an administrative, social, and cultural nature. People who have lost their space have also lost themselves. Indeed, civilizations have been built on madinahs. The industrialization that started during the $18^{\text {th }}$ century and gained speed during the $19^{\text {th }}$ century brought with it the concept of urbanization. Europe lost its concept of the medieval city and built cities parallel to the positivist, secular, and materialistic approaches of its traditions of thinking. The high-tech process that took place during the $1970 \mathrm{~s}$ following industrialization transformed the material universe and

Ilahiyat Studies

Volume 11 Number 1 Winter / Spring 2020

p-ISSN: 1309-1786 / e-ISSN: 1309-1719

DOI: $10.12730 / 13091719.2020 .111 .200$

Copyright (C) Bursa İlahiyat Foundation
\end{abstract}

Received: November 01, 2019 Accepted: January 03, 2019 Published: June 30, 2020

To cite this article: Dağ, Ahmet. "Losing Our Space/Madinah: From the Madinah of Reality to A Simulation City." Ilabiyat Studies 11, no. 1 (2020): 47-78. https://doi.org/10.12730/13091719.2020.111.200 
order into a simulative order. The present study focuses on how space and the city — and hence reality — have been lost by breaking away from the Islamic badārah (tamaddun) by way of the Baudrillardian simulation concept.

Key Words: Space-Humans, Madinnah-Community, Reality-Simulation

\section{Introduction}

The process of making law or science started with the rationalistempiricist synthesis of the $17^{\text {th }}$ century during the Enlightenment $\left(18^{\text {th }}\right.$ century) that replaced tradition and religion after Bacon, who aimed to dominate nature and society with the discourse of "knowledge is power." According to Baudrillard who had a critical approach to the roots of Enlightenment in the West intersecting with the Baconian approach, Cartesian mathematics, and Newtonian physics, nature in Western thought is nothing but a concept of a dominated essence that is claimed to replaced and reproduced by science and technology. ${ }^{1}$

"Naturalistic" ideological understanding presents itself in the construction of the city. Nature has been perceived all over the world as a social model since its emergence as a concept resembling décor or a structure model. Everything from a building to a small spoon or a city as a whole has been called an "object" following the emergence of an object-based approach in urban architecture based on the "naturalist" understanding. Asserting that the "naturalist" ideology has gained an objective, universal, and functional meaning in architecture thanks to Bauhaus, Baudrillard states that we are living in a universe where everything carries the qualification of a function and a sign. There is an unsystematic revolution devoid of a unique status based on objects and a rational goal (functionality). ${ }^{2}$

A new realization has emerged with the addition of Cartesian philosophy to Newton's "naturalistic" understanding of the universe. This new realization has resulted in industrialization and the

1 Jean Baudrillard, The Mirror of Production, trans. Mark Poster (St. Louis, MO: Telos Press, 1975), 55.

2 Baudrillard, For a Critique of the Political Economy of the Sign, trans. Charles Levin (St. Louis, MO: Telos Press, 1981), 197, 186. 
construction of the industrial city. The industrial city was shaped, arranged, and disciplined subject to human will during the $19^{\text {th }}$ century as the set of individual bodies established clear distinctions between the mind and the body. Urban space is related to the idea of a prosthetic extension of the human body, a diffuse and interconnected realm of human interaction founded on the blurring of boundaries rather than their delineation. ${ }^{3}$ Nature has been rediscovered and produced via science and technique. In the small spaces of natural parks and green areas reduced to a sample surrounded by the vast urban texture, the "rediscovery" of nature is actually the re-enclosing of nature. ${ }^{4}$

The scientific and technological advancement of the $18^{\text {th }}$ century took form in flesh and bone during the $19^{\text {th }}$ century by way of industrialization. The birth of factories and industrial zones followed by the popularity of communication tools such as newspapers, telephones, and telegraphs resulted in the emergence of cities and metropolises. Technological developments occurred following mechanical development. The process of urbanizationindustrialization-technologization gave birth to different forms of public life and service areas. Coupled with these developments, improvements in banking, shopping centers and the transportation sector resulted in changes in the characteristics and spirit of space and the individual. Industrialized cities and metropolises emerged that are spaces of artificiality, morbidity, and captivity dominated by different lifestyles, such as eating-drinking, fashion, and entertainment. ${ }^{5}$ These concentric, isomorphic, synchronic cities are singular and different from rural space, with a permanent revolution and intense circulation; one feels as if one is living in the same city

3 Wendy Steele et al. "The Cyborg City: Re-Thinking Urban Resilience Through Mobile Communications," in Proceedings of the SOAC 7 - State of Australian Cities Conference (SOAC 2015), ed. Paul Burton and Heather Shearer (Southport: Griffith University, 2016), 2.

4 Ahmet Dağ, Ölümcül Şiddet: Baudrillard'm Düşüncesi (Istanbul: Külliyat Yayınlar1, 2011), 192.

5 Henri Lefebvre, Everyday Life in the Modern World, trans. Sacha Rabinovitch (New York: Harper \& Row Publishers, 1971), 122. 
regardless of which city one visits in the modern world. ${ }^{6}$

The passion and struggle for "bread" and "entertainment" started to dominate in the gradually expanding world of petrified cities, bringing about the start of a new period against the countryman. The world-city that formed against the countryman built cosmopolitanism in place of "home." Civilization, which is the state of advanced humanity, is an external and artificial state. Those living in such a world-city do not make up a community but a crowd. In this case, they are death following life, rigidity following expansion, the intellectual age and the stone-built, petrifying world-cities following Mother Earth and the spiritual childhood of the Doric and Gothic. ${ }^{7}$ Cities are the constructs of civilization, whereas madinahs are the constructs of hadarah. Western cities carry the attributes of civilization, whereas Islamic cities carry the attributes of hadārah. While the European city design or Weber's city has a class "encounter," there is a corporate structure at the center of the community in the Islamic madinah "equalizing" the people. ${ }^{8}$ The land on which the population is increasing becomes the property of mankind, petrifying over time into a city. During this process, urbanization, or petrification, is indispensable, and the humans belonging to the city they own become a part of it and are thereby being affected by its character. According to Baudrillard, it is not space but time that determines whether an individual belongs to the city. ${ }^{9}$ Indeed, it was time and not space that was indicative during the Middle Ages and the Renaissance.

The spirit of the times (zeitgeist) affected and identified the people living during those times. While time identified the people, they in turn determined the madinah of the time they lived in together with space. In this context, the $19^{\text {th }}$ - and $20^{\text {th }}$-century-city was the perfection of modern space. It was the space of rationality and of industry, liberalism, and advancement. New architecture created a

6 Baudrillard, Cool Anılar I-II: 1980-1990, trans. Yaşar Avunç (Istanbul: Ayrınt1 Yayınlar1, 2002), 86.

7 Oswald Spengler, The Decline of the West Vol. I: Form and Actuality, trans. Charles Francis Atkinson (London: George Allen \& Unwin Ltd., 1929), 31-33.

8 Lütfi Bergen, Kenti Durduran Şehir (Ankara: MGV Yayınları, 2016), 389, 401.

9 Jean Baudrillard and Jean Nouvel, The Singular Objects of Architecture, trans. Robert Bononno (Minneapolis: University of Minnesota Press, 2002), 47. 
new community independent of the social, aesthetic, and philosophical accumulation of the $20^{\text {th }}$ century. Modern madinahs that are generally located at the center of large empires have resulted in a contrast between the madinah and village, the urban and rural, and the modern and passé. ${ }^{10}$ Attempts were made to depict and understand these contrasts, paradoxes, and rootlessnesses during the beginning of the $20^{\text {th }}$ century by C. Baudelaire and G. Simmel and towards the end of the century by J. Baudrillard.

To observe modern space, Baudelaire uses the flâneur, the city stroller, a modern person who does not participate in the city but is an ambivalent observer. The flâneur perceives the metropolis as a charming world of dreams, a cradle of modern living culture that is the center of sparkling night life. ${ }^{11}$ The modern man and flâneur of Baudelaire and Baudrillard are different from one another. Baudrillard's flâneur is glued to the seat in front of the TV screen; the leisurely wanderer is strolling no more. Now it is the TV images, advertorials, commodities, and various pleasures that stroll and wander opposite the hypnotized viewer. Baudelaire's leisurely wanderer has transformed into Baudrillard's viewer. ${ }^{12}$ In his article entitled "The Metropolis and Mental Life" (1903), Simmel presents various snapshots of life in the metropolis. The subject is the modern metropolitan individual with an intensified emotional life subject to rapid and ever-changing internal and external stimuli. Similar to Simmel, Baudrillard focused on the McDonaldization and Disneyfication of time in his book Simulations (1983) and proposed a whole new perspective on modern life in the metropolis with the concept of hyper-reality. ${ }^{13}$

10 Richard J. Lane, Jean Baudrillard (London: Routledge, 2000), 43, 104, https://doi.org/10.4135/9781446262313.

11 Charles Baudelaire, Modern Hayatın Ressamı, trans. Ali Berktay (Istanbul: İletişim Yayınları, 2004), 196.

12 Dağ, Ölümcül Şiddet, 54.

13 "Living in the Hyperreal Post-modern City," https://www.designingbuildings .co.uk/wiki/Living_in_the_hyperreal_post-modern_city, accessed January 30, 2020. 


\section{The Madinah Conception in Islamic Civilization (Tamaddun)}

The "madinah" belongs to religion and tradition, whereas the "city" belongs to industrialization and modernity and thus to the West. The city is a setup built by the financial successes of people (factories, shopping centers, stadiums, etc.), whereas the madinah is a constructed grid that protects the limits prescribed by Allah ( $b u d \bar{u} d$ Allāb) concerning the realm of nature as well as that of the invisible (al-ghayb/al-malakūt), which transcends nature. The city has enslaved its dwellers by way of cars and residences, numbing them through their subjection to its own functioning. ${ }^{14}$ Modernist structures settle down in traditional madinah architectures much like tumors, transforming what is natural and humane into a virtual and bestial city. In a sense, this is the replacement of the perception and construction of the madinah by the ancients ( $\left.a l-q u d a m \bar{a}^{\prime}\right)$ with the metaphysical sentiment of a modern radical and purely rational way of thinking. Cities based on pragmatic engineering that is beyond measure are constructed in place of the madinah, which is based on deep, rigorous metaphysical principles that require significant effort. The madinah is now being rectified with its metaphysical architecture, which requires a long and arduous effort with a purely mathematical (disproportionate) approach. Virtual technology is pragmatically and radically eliminating the madinah and its architectures, with their historical, intensely moral, and philosophical culture. Islamic madinah architecture is also affected by the rationalization, pragmatism, practicality, and individuality of the construction of the city. The Islamic architecture based on being and the identity of the eternal encompasses the association of part-whole, and individuality loses its significance. The parts are continuously in motion to reach unity. Unity (al-tawhid), which is the basic principal of Islam, also has reflections in Islamic architecture, embodying and responding to problems as a whole. ${ }^{15}$ Order (al-'adālah/al-nizām; putting everything in its appropriate place) is attempted to be established in Islamic madinah architecture. Architecture occurs at the material, biosocial, psychological, and spiritual/mental planes and

\footnotetext{
14 Bergen, Kenti Durduran Şehir, 89, 98.

15 Turgut Cansever, "İslam Mimarîsi Üzerine Düşünceler," Divan: İlmî Araştırmalar 1, no. 1 (1996), 127.
} 
encompasses all areas of being. Rather than being a field of technology, architecture is the product of the subjects of morals and religion and embodies the considerations of being. According to Cansever, the Western world tried to overcome philosophical problems by a narrow, limited, and dualist conception of being, concentrating its attention only on the material and spiritual planes. The concept of tawhid in Islam surpasses these flaws, stipulating the efforts of grasping the unity of being. ${ }^{16}$

This tawhi $\bar{d}$ approach is reflected in the construction of the madinah. Administrative and economic units manifest themselves as "house-mạ̧allah-madinah," constructing a tamaddun. ${ }^{17}$ Dwellings with courtyards inside them are surrounded by tall and windowless walls. This "home" structuring provides privacy and security. The courtyard also provides a green environment where children are free from dangers, and life in the courtyard passes with production. ${ }^{18}$ The house that takes shape in Islamic architecture, generally around a courtyard that separates it from the outside world, is composed of two sections: haram (the private domain) and selamlik (a room set apart for guests/visitors/outsiders) in Turkish. People are not allowed to sit on the street in an Islamic madinah since there are other places (masjids and homes) for sitting and gathering. Streets are described by homes. Homes, which are the representation of mortality, are constructed using short-lived materials such as wood or adobe brick; thus, meeting the need for transformation in the madinah is simplified. The order of the homes is an indication of mutual respect. ${ }^{19}$ Irregular streets (dead ends or winding streets) and the closure of streets to pedestrians serve the functions of privacy and security. ${ }^{20}$ Irregular road patterns and courtyard-centered homes are ever-present in the ancient East. The division of the city into living spaces and the marketplace as the central business area is a

16 Ibid., 120.

17 Bergen, Şebir Sünnettir (Ankara: Hitabevi Yayınları, 2016), 213.

18 Bergen, Evlerimizi Kaybediyoruz: Yerlilik Meselemiz (Ankara: MGV Yayınlar1, 2016), 235.

19 Cansever, "İslam Mimarîsi Üzerine Düşünceler," 130.

20 Yılmaz Can, "H.I-III./M.VII-IX. Y.Y. İslâm Şehri," Ondokuz Mayıs Üniversitesi Ilâhiyat Fakültesi Dergisi 6 (1992), 115. 
distinctive criterion for the Near Eastern madinah, considered the cultural heritage of Islam. ${ }^{21}$

The courtyards for privacy, known as "Hayat (Life)," are abandoned for "balconies" that enter the privacy of others who expose their own privacy. Cansever states that the privacy of a home and the conception of home as a secluded and private space are interrelated expressions. Social unity and solidarity, security, individuality, and privacy are important elements for Islamic home architecture. ${ }^{22}$ Quarters, as social spaces that find life through select people with equivalent moral values, were locations with open marketplaces where women acted as mothers in addition to selling their own products. ${ }^{23}$ These spaces were not hypermarket-style centers of trade that destroy the traditional, as proposed by Baudrillard, but places of an approach involving a modesty in income. Wide boulevards or streets have been built for modern society instead of quarters that involve such a sense of community.

Asserting that modern society renders the sense of community involving the concept of mahallah impossible, Bergen states the following:

Mahallah is not a social element in the modern city. You cannot build a mahallah from hundreds of apartment blocks placed side by side. You can only put forth a definition such as, "place of residence" or "İstiklal Street," "Yüksel Street." These locations cannot be an area of life or social identity. They can only be the gathering places for different individualities. It may perhaps represent a ghetto. That is, it comprises closed communities involving polarization and "marginalization" according to social identity, whereas "maḥallahs" are organizations where a group of people who are not homogeneous/of the same class gather without "marginalization," building a "superordinate identity." 24

The Islamic madīnah does not represent a single type of

21 André Raymond, "The Spatial Organization of the City," in The City in the Islamic World, ed. Salma K. Jayyusi et al., (Leiden \& Boston: Brill, 2008), 57, https://doi.org/10.1163/ej.9789004162402.i-1500.15.

22 Cansever, "İslam Mimarîsi Üzerine Düşünceler," 123.

23 Bergen, Evlerimizi Kaybediyoruz, 234.

24 Bergen, “Medeniyetin Cüzü: Mahalle,” Ideal Kent 2 (2010), 144-145. 
civilization like Greek or Roman city. ${ }^{25}$ Lives for single people have been constructed in neighborhoods composed of $1+1$ flats that destroy the mahallah life. Therefore, the madinah and the OttomanIslamic madinah architecture that provide a unique architectural taste have been abandoned. It is not possible to catch a glimpse of the primeval joys and aesthetics of building madinahs in cities established during the Republic Era (Kırıkkale, Karabük, Tunceli, Batman, Gölcük, Kapaklı, Çerkezköy). Whereas the madinahs built by the Andalusians, Seljuqs, Ottomans, and even Ghaznawids have architecture with unique and traditional characteristics, the cities built during the Republic period with the aim of westernization are devoid of these architectural characteristics. It is not clear to which culture the constructed madinah (excluding historical spaces) belongs.

In general, places of worship and marketplaces have an important impact on the process of madinahzation. Specifically from an Ottoman perspective, they are described as "Cuma kilınur, bazar durur (Friday prayer is performed, bazaar settles down)" based on historical documents. Beamlike roads spread out from the mosque located at the center in many Islamic madinahs. Marketplaces have also started to gather around the mosque community; therefore, the number of marketplaces has increased subject to the number of mosques. ${ }^{26}$ The madinah center, closed bazaar, or bedesten (a lockable, covered [usually domed] building where valuable goods were stored) is organized around the great/grand mosque. ${ }^{27}$ Three elements that the Ottoman madinah has acquired from Islam are the mosque, the marketplace, and the Turkish bath. The madinah is structured around the mosque and the marketplace. ${ }^{28}$ Indeed, the "Friday mosque" and "marketplace" were two important catalysts with regard to the construction of the madinah for the Ottomans. Accordingly, it is understood that the "Friday mosque" and "marketplaces" set up on certain days of the week make up the essence of the madinah. Indeed, mosques and almshouses (imaret/'imārah) are important with regard to madinah construction and architecture in the Ottoman era. The old bazaars were

\footnotetext{
25 Raymond, "The Spatial Organization of the City," 52.

26 Can, "H.I-III./M.VII-IX. Y.Y. İslâm Şehri," 116.

27 Raymond, "The Spatial Organization of the City," 59.

28 Bergen, Kenti Durduran Şehir, 47.
} 
abandoned during the first years of the Republic, leaving in their places "statue"-centered marketplaces, whereas "hypermarket"centered marketplaces started to be built during the 2000s.

Sociocultural, religious, and commercial elements such as the imaret, bedesten, caravanserai, marketplace, and Friday mosque (grand mosque) make up the texture of the madinah. The Ottoman madinah presents an integrity that brings to mind the concept of an Ottoman madinah with its physical characteristics, economic development, and functional structure. Building imarets, which are religious and social structures for developing the madinah further, is one of the characteristics of the Ottoman madinah and make it superior to other Islamic madinahs. Order and respect have been taken as the basis for the construction of the houses in these madinahs. Security, the Islamic belief system and thus privacy, respect, and modesty are the important factors that determine the locations of the homes with respect to each other. These sensibilities were lost over time subject to changes in the form of belief.

\section{Madinah as a Concept and Part of Architecture}

The architecture that is a part of the madinah is the means by which people rearrange their madinahs for their existence. It is equivalent to considering the madinah solely as a work of art and giving it an aesthetic form. In addition to architects, painters, sculptors, and ceramists, there is a need for madinah designers with an artistic sensibility and new madinah planners who are also aesthetes and thinkers. Contrary to the Middle Age and Renaissance periods, benefit and functionality have been considered as the basis during the era of rapid industrialization. ${ }^{29}$ In this regard, Turgut Cansever considers architecture a noble act of people that "encompasses all areas of being while developing life at material, biosocial, psychological, and spiritual/intellectual levels encompassing all areas of being while also having complex relations with the problems brought about by life." 30

\footnotetext{
29 İsmail Tunalı, Tasarm Felsefesi: Tasarm Modelleri ve Endüstri Tasarmm, $4^{\text {th }}$ ed. (Istanbul: YEM Yayınları, 2012), 47.

30 Cansever, İslâm'da Şehir ve Mimari, $11^{\text {th }}$ ed. (Istanbul: Timaş Yayınları, 2016), 8.
} 
Urban planning of the private sector and its understanding of development, order, and administration has taken the place of the madinah in the feudal order. The city has been built in this framework, as a result of which the elite and middle class that make up urban colonialism emerged. Baudrillard examines this emerging postmodern city:

The urban city is also a neutralized, homogenized space, a space where indifference, the segregation of urban ghettos, and the downgrading of districts, races, and certain age groups are on the increase. In short, it is the cut-up space of distinctive signs. Multiple codes assign a determinate space-time to every act and instant of everyday life. The racial ghettos on the outskirts or in the city center are only the limit expression of this urban configuration: an immense center for marshalling and enclosure where the system reproduces itself not only economically and spatially, but also in depth by the ramifications of signs and codes, by the symbolic destruction of social relations. ${ }^{31}$

The capitalized city is like an entity that is growing every day. People rush to these cities that are constructed on the mind-body duality. In the language of economics, it is almost as if an excessive amount of product/spirit is introduced to the market/society. Cities built by Cartesian thought are populated not only by bodies but also by excessive amounts of information, informatics, communication, and social networks. The city is a location people rush towards as a center of attraction. The city is the location of this increase and "chain reaction" approved by the holistic dictatorship of fashion. The intensive urbanization process of rural areas via rapid acculturation is irrecoverable and unstoppable. The discourses of the city (impulses, desires, stimulations, judgments, eroticization, information, stimulation of advertisements) are as determinant with regard to the fate of the society as is the population density of the city. ${ }^{32}$

J. Nouvel, who conducted an interview with Baudrillard stating that it is not possible to prevent the growth of the city and

31 Baudrillard, Symbolic Exchange and Death, trans. Iain Hamilton Grant (London: SAGE Publications, 2017), 97.

32 Baudrillard, The Consumer Society: Myths \& Structures (London: SAGE Publications, 1998), 65-66, https://doi.org/10.4135/9781526401502. 
urbanization, claims that the rush towards cities leads to a sort of urban big bang by enabling the making of plans and the placing of rules; hence, ready recipes and architecture have now become futile, indicating that the system becomes absurd as soon as it is combined with a structural model. ${ }^{33}$ Urbanization has brought about rapid modernization leading to the desertification of the country by dehumanizing villages and rural areas. ${ }^{34}$ Speed and growth have resulted in an increase in the number of cities as well as urbanization. The discourses of the city have led to individuals focused on speed and desire and the fast cities built by these individuals. The term fast cities is used to define rapidly growing or, in other words, economically booming cities. Reference is made to their growth centered on trade and economy. Such cities characterized by innovation, entrepreneurship or fast economy and spatial growth express the success story of global neo-liberal urbanism.

The historical, social, and political abilities of intensive and fast city-region urbanizations vary subject to this success. The history of fast urbanizations leads to colonial and post-colonial social divisions with the rapid urbanization of the $21^{\text {st }}$ century. Fast structuring is related to urbanization, migration, and climate change. Fast cities that give birth to post-colonial insecurities around modernity, development, and ownership can be considered the re-emergence of the post-colonial state desire, which is different and separate from classical colonialism. Fast cities are considered an extension of neoliberal city development in Asia, Africa, the Middle East, and Latin America. Various solutions are proposed against fast and growing madinahs. As new towns, industrial cities, and satellite cities are built, the logic of metropolitanism or "bypass urbanization" for building new cities through the growth of already existing cities is supported. Mega cities emerge by channeling capital, resources, and services away from the already existing cities. ${ }^{35}$

The fast growth and post-colonialization of cities results in the alienation of the individual from his/her society. Baudrillard depicts

\footnotetext{
33 Baudrillard and Nouvel, The Singular Objects of Architecture, 17.

34 Bergen, Kenti Durduran Şebir, 100.

35 Ayona Datta and Abdul Shaban, Mega-Urbanization in the Global South Fast cities and new urban utopias of the postcolonial state (London \& New York: Routledge, 2017), 4-7.
} 
this by telling the story of Ishi, the last member of an Indian tribe who was stupefied by the sight of the vast crowds in San Francisco. He could only think that the dead - all the previous generations - were also there among the living. This is what happens when the whole space is suffocated by our state of overpopulation, over-information, and over-communication, leading to the mass state where the living become strangers to one another and only the living dead remain. ${ }^{36}$ According to Baudrillard, cities are large structures that are never left alone; there is always work going on - digging, demolition, construction, knocking down, and building up again with domestic luxury and suburban comfort. ${ }^{37}$ New York, Chicago, Houston, Seattle, and Toronto have reached a dramatic state due to giant buildings built out of competition resulting in the birth of an object/city that ignores the benefits of society and the individual while insisting on its madness outside the control of architecture. The only thing that is equivalent to this object is the arrogance and challenge of Renaissance cities. ${ }^{38}$

Practical design has taken a place compatible with the theoretical concept of the environment and in accordance with the Newtonian understanding of "nature" as well as Cartesian philosophy. The functional sector with environmental balances during this process is the form of sending/receiving messages and space/time that is unique to communication. This means that a universe encompassing all applications and forms from daily life to architecture, speech to body language and politics has become self-ordained. ${ }^{39}$

The Renaissance aimed to revive the past and build paradise. Building paradise is one of the comfort-related goals of modern architecture. However, the practical counterpart of the desire for a lost paradise or taking refuge in the past is difficult. The paradise place (!) of industrialization and modernization, the city, has been transformed into an area of product manufacturing, industrial businesses, and intensification. Cities where the automation process takes place are places of the living dead where masses are physically

\footnotetext{
36 Baudrillard, Imkânsız Takas, trans. Ayşegül Sönmezay (Istanbul: Ayrınt1 Yayınlar1, 2005), 18.

37 Baudrillard, Cool Anilar I-II, 227.

38 Baudrillard, Imkânsız Takas, 29.

39 Ibid., 256.
} 
close to each other but are spiritually miles apart. The city is the place where modern people are allowed to lead lives as the living dead.

Asserting that architecture operating by way of a piece of land/territory to take shelter in and to defend will always have a place for itself even when the forms of civilization change, Baudrillard suggests that architectural acts as sources of pleasure that are in relation with new data will always be present despite the assumption that the city has disappeared both physically and territorially. ${ }^{40}$ As proposed by Baudrillard, the city and architecture will continue their presence for as long as there are people and lands. However, the city takes on a different form together with architecture. While the cities built during the $19^{\text {th }}$ century had a mechanical characteristic, virtualtechnological cities were built during the $20^{\text {th }}$ century, and digitalsmart-transhumanist cities were built during the $21^{\text {st }}$ century. In particular, Western cities face different crises in every decade. Industrial pollution during the $19^{\text {th }}$ century, excessive migration during the start of the $20^{\text {th }}$ century, destruction caused by the Second World War during the second quarter, city riots during the 1960s, rapid increase of commercial spaces during the 1970-1980s, and security syndromes during the post-9/11 era can be given as examples. The growth of metropolises and humane issues has resulted in the emergence of various exemplary cities such as the "garden city" (E. Howard), "radiant city" (Le Corbusier), "sustainable city," "smart city," and "eco-city" as suggestions for solutions.

\section{Hypermarkets as Mechanisms for Transforming the City and the People}

There is the classical period with the copying of forms corresponding to the order of triple simulacras (nature-manufacturersimulation simulacras), the industrialization age involving the production of form products, and the simulation age involving form simulation. Indicators of the age of industrialization are industrial systems, machines, and factories. There are automatons and robots in the simulation period dominated by technology that criticizes this period; this period corresponds to the communication revolution. ${ }^{41}$

\footnotetext{
Baudrillard and Nouvel, The Singular Objects of Architecture, 79.

41 Dağ, Ölümcül Şiddet, 178-179.
} 
According to Baudrillard, while industrial capitalism is the process of production, the modern world's morals that dominate the simulation order are consumption. The process has transformed from production as the basis to consumption as the basis. Factories were established at strategic locations in city centers during the onset of industrial capitalism and later shifted to locations outside the city centers. Shopping centers that symbolize consumption have taken the place of factories that symbolize production in the urban structuring that guides urban life and relations. It holds a central position in today's consumer society, urban life, and structuring. In the words of Baudrillard, who considers the hypermarket as exceeding the "consumption center," the new cities have become the satellites of hypermarkets. The hypermarket is an indication that rural areas have transformed into urban areas as well as the expression of a new way of life. The products here that symbolize social relations have been organized for viewing. ${ }^{42}$ In this sense, the hypermarket with new modes of consumption is a postmodern space generating new geographical and experiential spaces that determine what is social rather than being an architectural construct. ${ }^{43}$ According to Baudrillard, the city that has transformed itself into a metropolitan area cannot absorb the "negative satellites" that are the new areas of existence. Cities as spaces of trade, work, information, and free time have become seductive, dislocated, and indistinct. ${ }^{44}$

The structure of cities was damaged as they transformed into satellites of hypermarkets or shopping centers rather than primal modernization. Cities that transform into satellites are moved to hypermarkets, giving way to suburbs. A new form of structuring has emerged with nuclear and satellite attributes along with molecular characteristics resembling the genetic code and cybernetic characteristics resembling command scenarios. The hypermarket as a nucleus that even the modern city fails to absorb takes the suburbs, factories, and the university into its orbit. It is a space that has made the city its satellite by surpassing the factory of the $19^{\text {th }}$ century, which

42 Mehmet Anık, "Aykırı Bir Düşünür Olarak J. Baudrillard ve Gösteriş Amaçlı Tüketim," Uluslararası Sosyal Araştırmalar Dergisi 9, 47 (2016), 449, http://dx.doi.org/10.17719/jisr.2016.1391.

43 Lane, Jean Baudrillard, 24.

44 Ibid., 104. 
does not disrupt the orbit of the city. The hypermarket, as a hyperrealistic model resembling a social synthesis disconnected from the city, is like a giant assembly line. The hierarchical work order is replaced by employees (patients) who come and go as they please to choose, buy, and gape. There is a well-programmed disciplinary order and an assembly line where prohibitions are hidden behind a false façade of tolerance, convenience, and hyper-reality. It cannot be taken into consideration separate from the city, resembling a functional screen that reflects the highways, parking, and all activities. Hypermarkets that exceed the spaces of capital are models that gather prospective social control and ways of life (work, leisure, food, hygiene, transportation, media, culture) under a single homogeneous roof (time/space). The hypermarket as the reinterpretation of all opposing movements in a closed circuit is the space where time-space is integrated and where social life and a functional simulation are in place. ${ }^{45}$

The philosopher who does not only claim that the hypermarket pulls the city into its field of attraction and orbit relates the world to the hypermarket that is a functional, continuous, and singular living thing. Decentered and deterritorialized hypermarkets have been modeled on traditional downtown shopping areas. They have transformed their zones not only architecturally but also with regard to the social way of life. They have developed a new mode of living and experiencing social spaces, even taking the place of organized religion in developed countries. Hypermarket shoppers have started to be screened with regard to the products they purchase. ${ }^{46}$ According to Baudrillard, the hypermarket is one of the indicators of the simulation order that enable us to understand how modernity, which has a meaning beyond the consumption center, will end.

According to Baudrillard, the hypermarket as a model heralding the future acts as an orbit (especially in the USA) because it determines the distribution of the areas of settlement. Thus, the hypermarket that gives an order to all that takes place around it is the homogenizing boiling point where all differences melt and become

45 Baudrillard, Simulacra and Simulation, trans. Sheila Faria Glaser (Ann Arbor, MI: The University of Michigan Press, 1994), 76-77.

46 Francesco Proto, "Architecture," in The Baudrillard Dictionary, ed. Richard G. Smith (Edinburgh: Edinburgh University Press, 2010), 18. 
one. Traditional marketplaces in downtown city centers paved the way for citizens and villagers to get together, whereas the hypermarket destroys the villager and the traditional. ${ }^{47}$ Hypermarkets as spaces of pseudo-centralization that are neither centers nor peripheries shape a pseudo-area around them, transforming the city into a satellite. Hypermarkets that are indications not of urban integrity but decomposition, not of order but disorder, do not establish accordance with the city and its shopping relations; on the contrary, other-worldly objects overshadow the city like space vehicles that have managed to break through from a dark disaster. It seems for Baudrillard that there is no escape from this. What should be done is to allow the hypermarkets to come and go as the monsters they have become. Since hypermarkets as urban monsters are not monuments but monsters, it will be of no use to banish them from cities or districts. ${ }^{48}$

Hypermarkets, as immaculate examples of new and strange spaces replacing the marketplace with which they have ruptured their relationship, are nuclear plants with the power to dissuade, and their hidden function is dissuasion. Hypermarkets that have become simulation poles have regressed modernity by determining the actual elements (traditional transportation systems and factories) of the preceding city and pacifying them. The desire of the hypermarket that swallows the past and the present, allowing only the present moment to live, in turn results in new forms of depression or disaster. ${ }^{49}$

Baudrillard, who presented an ironic analysis of consumption, hypermarket, and hyper-product, bases his human-space analyses on culture and shopping centers such as Beaubourg and drugstores. According to him, Beaubourg, as a center of cultural exchange in addition to being a center of consumption, is the space of the simulation order, which indicates that Western culture is hyper-real..$^{50}$ Beaubourg's architecture is also in accordance with its cultural function, so it has been built in a sort of hyper-real fashion. When considered from the point of view of architecture, Beaubourg is one

\footnotetext{
Baudrillard, Simulacra and Simulation, 75-76.

48 Baudrillard, Cool Anilar I-II, 104-105.

49 Baudrillard, Simulacra and Simulation, 77.

50 Dağ, Ölümcül Şiddet, 134.
} 
of the first attempts to objectify the plug-in city concept ${ }^{51}$ of Archigram. $^{52}$

Beaubourg, which resembles a hypermarket with no memory and whose true output is not art and culture but only a form of the masses and the mass anti-culture, is the simulation of the homogeneous void of society. Taking the place of the factory, Beaubourg is a hyper realistic labyrinth as a space of division, entertainment, simulation, and implosion. Beaubourg provides the massive transformation of traditional culture with its power to homogenize. This architecture that is part of the simulation order is also a part of anti-culture. In the world of touch and manipulation, Beaubourg transforms humans into an entity that wants to capture everything, eat everything, and touch everything. Organizers have been alarmed by this uncontrollable impulse. ${ }^{53}$

Beaubourg is a center of culture resembling a mechanical science fiction creature spreading beams of light, a dead and frozen metabolism erected to commemorate a hyper-realistic culture that is completely disconnected from society. It disconnects the individual from time, teaching that social life is a space-time belonging to the operational simulation, that the goods are hyperreal, and that the hypermarket culture is hyper-realistic. Masses that enter Beaubourg do not obey the official culture, crush and eliminate the myth of the system, imitate and play with patterns, do not deal with the meanings of cultural objects, and know that meaning is not present but that simulation is. ${ }^{54}$ Drugstores, as modern consumption centers, are locations instilled with a pint of intelligence and human warmth where culture and commodities are culturalized. The entire objective social life is glorified in this space where artificial climates and seasons are brought into existence. Drugstores/pantheons, considered modern centers of consumption corresponding to the pantheon of Ancient Rome, bring forth a unique and new culture and style that culturalizes people. As a new culture, drugstores comprise a

51 Baudrillard and Nouvel, The Singular Objects of Architecture, 38.

52 A group of avant-garde architects during the 1960s started by P. Cook, W. Chalk, R. Herron, and D. Cromption.

53 Mike Gane, Baudrillard's Bestiary: Baudrillard and Culture (London \& New York: Routledge, 2003), 144-145, https://doi.org/10.4324/9780203415856.

54 Dağ, Ölümcül Şiddet, 121. 
new style involving human warmth and intelligence. Such shopping styles and consumption habits have shaped the dimensions of our communities and the morals of today's world. ${ }^{55}$

Asserting that even animals construct a lifestyle and relations based on accumulation, the philosopher states that animals put into action thermodynamic information exchange mechanisms to maintain their existence. ${ }^{56}$ Whereas the hypermarket is the place of the simulation order, masses are the communities of the hypermarket. Baudelaire's urban wanderer has been replaced by Baudrillard's individuals wandering in shopping centers or drugstores. Excessive consumption is an indication of the presence of the individual in the consumer society. Baudrillard's market wanderers witness the nighttime dreamlike scenes of shopping spaces. Keen on consuming, dressing up, and eating, the individual is an entity of consumption that appreciates himself/herself and has become an object of seduction. ${ }^{57}$ Hypermarkets as spaces that detach the individual from reality and the natural environment are among the most important elements related to the formation of the virtual city.

\section{Virtual and Digital Cities Detached from Reality}

Just as the "messianic hope" is based on apocalyptic reality, Baudrillard sees the end of humanity not as "actual" but as "virtual," claiming that individuals trapped in the virtual reality of the simulation will never have the right to enlightenment. ${ }^{58}$ It is difficult to find reality in the simulation. Simulations and hyper-reality overloaded with images eliminate the borders between reality and representation. Hyper-reality or simulation is defined as the generation via models of a reality devoid of roots or actuality. There is no longer any territory before or after the map. ${ }^{59}$ The disruption of the difference between reality and simulation reflects the characteristics of time and space. The territorial region no longer comes before the map, and it is the map that generates the territory. ${ }^{60}$

\footnotetext{
55 Gane, Baudrillard's Bestiary, 18-21.

56 Baudrillard, Simulacra and Simulation, 141.

57 Baudrillard, The Consumer Society, 103.

58 Datta and Shaban, Mega-Urbanization in the Global South, 61.

59 Baudrillard, Simulacra and Simulation, 2-3.

60 "Living in the Hyperreal Post-modern City."
} 
According to Baudrillard, the map no longer corresponds to an actual territory; rather, it comes first and indeed is the map that brings the territory into existence. The new territory that is almost the simulacra has been built on reality (terrain). Las Vegas, as the immaculate city of advertising with neon lights, bright streets, and radiance of advertising, is a simulacra city that puts the individual inside a surprising hyper-reality. ${ }^{61}$

According to the philosopher, who uses Disneyland, which he considers as the model of simulacras, to describe the construction of the virtual-simulation city by the clearing up of the traditional city through hypermarkets, the imaginariness in Disneyland is neither true nor false. Disneyland is a blanket hiding the fact that it is the real America. All of Los Angeles and America that surrounds Disneyland are no longer real but belong to the hyperreal order and to the order of simulation. In the section titled "The Hyperreal and the Imaginary" of his Simulacra, analyses of Disneyland, which represents the micro-world of the West, are presented as a simulation example. According to him, Disneyland is a perfect model of all the entangled orders of the simulacra with the real and reference systems, a play of illusions and phantasms, a deterrence machine set up to rejuvenate the fiction of the real, and a world where adults come to be childish. Disneyland, as the first great toxic excrement of a hyperreal civilization, is an ideological setup and universe enabling adults forced to believe that everything else is real to be childish and to make them believe that they are not actually children. ${ }^{62}$

G. Ritzer explains the transformation of society by McDonaldization, whereas Baudrillard describes the transformation of the city with the concept of Disneyfication. These two processes are connected through excessive stimulation and hyper-reality issues. The two processes active in the emergence of urban space McDonaldization and Disneyfication - established this simulated cycle of space developed by entertainment developers in the attempt to capitalize on the mental image of a space. Disney World is a new

\footnotetext{
61 Baudrillard, Simulacra and Simulation, 90-91.

62 Ibid., 28-30.
} 
model for creating a public space through spatial control and stimulated/simulated visual culture. ${ }^{63}$

The advancement of industrialization, technology, and cybernetics has brought about rational and economic institutions in modernizing communities, leading to differences and innovations. Primary relations have been replaced by artificial relations in communities with people living in smart buildings and smart cities. People have constructed comfortable residence blocks, shopping centers, cinemas, and brightly lit streets that will save them from the ordeals/realities of life. Modern cities have been built in the world of technology and cybernetics. It is almost as if the multitude of new smart building technologies, residence blocks, and offices detach the people from the natural world or, in other words, reality, constraining them to virtual spaces of "make believe" and thus leading them to live the virtual as the reality.

For Baudrillard, modern architecture presented virtually through technologies such as $\mathrm{CAD}^{64}$ produce completely functional architectural objects. Risk and drama are completely "programmed" through modern architectural projects in the city devoid of threats and risks and thus its bizarre interests. ${ }^{65}$ Spaces isolated from reality, distanced from pain and drama, have transformed people into the virtual or to the people in Plato's cave who take the shadows on the wall as reality. While those inside Plato's cave are the owners of the cave, those living in the city have given up on being the owners of the city only to perceive what takes place around them not within the framework of their own perceptions but through the images imposed upon them. Baudrillard claims that cities have been subject to miniaturization by an infinitesimal memory that forgets nothing and that belongs to no one. For him, the city is a simulation of an imminent, increasingly dense, irreversible order, one that is potentially saturated and that will never again witness the liberating explosion. ${ }^{66}$ Aspects that enable the reduction of the city to smaller dimensions are communication networks and transportation connections. The shrinkage of the city transforms the nodes of the

\footnotetext{
63 "Living in the Hyperreal Post-modern City."

64 CAD (computer aided design/computer aided manufacturing).

65 Datta and Shaban, Mega-Urbanization in the Global South, 26, 61.

66 Baudrillard, Simulacra and Simulation, 73.
} 
city (streets and hypermarkets) into economic centers of power. The transformation of cities into economic centers of power results in competition among them to attract global businesses, skilled workers, and eager consumers. ${ }^{67}$

The use in modern buildings (offices, residences, and hypermarkets) of iron and glass with advancing technology reduced these spaces almost to a state of steel and transparent cages. Iron and glass symbolize the power and obscenity of modern societies. Indeed, Las Vegas, which has created its own magic, is, as Baudrillard would suggest, the pride of capitalists and transsexuals. Cities composed of such spaces are indications of both seduction and virtuality. The city puts forth a unique reality of its own with illuminated and glass architectural structures. Similar to Beaubourg and Disneyland, Baudrillard perceives the Pompidou Center more as a space with a cultural function rather than a shopping and entertainment center. The interlocutors of this center that enable the circulation of these masses in the city beyond the carnival environment are not the radical groups of 1968 but rather the terminal citizens of the silent majority. This space provides its interlocutors an area where an artificial loneliness is secreted, transforming them almost into bubbles. The silent majority of cities, that is, the masses, live in a state of melancholy. ${ }^{68}$

The city (Los Angeles) resembles a fictional scenario and neverending travel, much like electrical and nuclear reactors or cinema studios. Los Angeles needs a discredited old imaginariness comprising falsified phantasms like childish shadows, similar to a sympathetic nervous system. Centers like Beaubourg and Pompidou are unreal systems that are in continuous motion (movement of vehicles, humans, etc.) that utilize the energy of the metropolis (Los Angeles) devoid of space and dimension. ${ }^{69}$ Continuous movement leads the individuals of masses in the city to be worn out. Not only the individual but also the city gets worn out in its entirety. Proposing New York as an example, the philosopher indicates that it is a miracle that the city starts afresh the next day after depleting all its

\footnotetext{
67 "Designing Smart Cities," accessed August 15, 2018, https://www .designingbuildings.co.uk/wiki/Designing_smart_cities.

69 Baudrillard, Simulacra and Simulation, 13.
} 
energy during the previous day. He ironically suggests that the city takes its energy from its noise, its wastes, and carbon gas. The expense in the city has transformed completely into a show and is supercharged by its own image. ${ }^{70}$

Modern architecture that needs territory no matter what not only destroys the space but also leads to a real fictional space by building sprawling, limitless cities. Just as humans, nature and history are not transcendent, the "savage mind" has no natural universe. There is an aspect in dance, cinema, novel, fiction, and architecture and especially all that is American that does not know of the radiance, pathos, rhetoric, and theatric characteristics of savage, Western bourgeois culture, which has not been adorned with the colors of cultural distinction. ${ }^{71}$ According to Baudrillard, who states that the old madinahs have a history, there is a savage sprawl in American cities characterized as real bombs disguised as cities with no concerns related to madinahs. ${ }^{72}$ These cities have acquired in fifty years the beauty that has taken centuries for madinahs to acquire. ${ }^{73}$

While the city during the $19^{\text {th }}$ century is a mechanical space with political-industrial aspects, it is a virtual space of indicators, tools of communication, and codes during the $20^{\text {th }}$ century. However, cities take on a digital identity in the $21^{\text {st }}$ century. The digital age, as the second industrial age after the age of industrialization, has completely changed the concepts of population, materialization, and the increase of knowledge, permanence, and transience. The emphasis on madinahs transforms dramatically from concrete structures to more complex and flexible structures along with soft (digital and ecological) infrastructures. ${ }^{74}$ It is now only a dream to revive the cities figuratively and content-wise that have been renewed in accordance with the reproduction scheme (restored after the Second World War) related to the scheme of a general production or revival. Cities can

70 Baudrillard, The Transparency of Evil: Essays on Extreme Phenomena, trans. James Benedict (London: Verso Publications, 1995), 102, https://doi.org/10.2307 1432045 .

71 Baudrillard, America, trans. Chris Turner (London \& New York, NY: Verso Publications, 1989), 101.

72 Baudrillard, Cool Anilar I-II, 239.

73 Baudrillard, America, 13.

74 "Living in the Hyperreal-Post-modern City." 
now continuously repeat themselves over time by way of an accumulated cybernetic memory resembling a genetic code. ${ }^{75}$

Every age gives birth to madinahs that are in line with the spirit of the time. Modern times have built new cities as their indicators. The urbanization ratio of rural towns increases, and accordingly, the city that is under threat due to increasing population, rising sea levels, climate changes, and diminishing resources should be a sustainable model. Governments of both developed and developing countries not only claim to improve social conditions but also wish to provide better economic conditions for their communities. For this purpose, there is a need for more flexible and environmental forms of madinahs. ${ }^{76}$ Baudrillard puts forth the following analyses intending sustainable architecture that designs flexible and environmental madinah forms:

Architecture is in fact a domain where the opposition ephemeraldurable is very evident to the imagination. For a certain architectural avant-garde, the truth of the dwelling of the future is in ephemeral construction, in detachable, variable, and mobile structures. A mobile society ought to have a mobile dwelling. And it is undoubtedly true that this is inscribed in the economic and social demands of modernity. It is true that the social deficit represented today (and increasingly in the future) by hard and durable lot construction is colossal: it contradicts the economic rationality and that of social exchanges, and the irreversible tendency toward more social mobility, flexibility of infrastructures, etc. But if for all these reasons ephemeral architecture must one day be the collective solution, for the moment it is the monopoly of a privileged fraction whose cultural and economic standing permits it to question the myth of durability.

It is because generations of the bourgeoisie were able to enjoy the fixed secular decor of property that their heirs today can give themselves the luxury of renouncing uncut stone and exalting the ephemeral: this fashion belongs to them. By contrast, consider all the generations of lower classes $[\ldots]^{77}$

\footnotetext{
75 Baudrillard, Simulacra and Simulation, 71.

76 "Designing Smart Cities."

77 Baudrillard, For a Critique of the Political Economy of the Sign, 51-52.
} 
The planning, design, and construction of new-generation cities have made an integrated approach necessary, leading to the concept of The Living City as an alternative terminology supported by technology. It has given birth to the techno-digital city within the context of the ideal city of our day in which we experience cybernetics and advanced technology. These cities that aim to adapt to changing conditions are dynamic rather than static and have techno-city characteristics rather than being mechanical. While the mechanical city is an expert and authority-centric city based on intensive planning and sudden changes, the living city is one based on trial and error, gradual change, and social networks. ${ }^{78}$ In this context, the citizens of Tokyo, composed of networks, are sophisticated consumers as entities of a crowd. This sophisticated consumer is also in need of a space for accommodation as a working human being. They are individuals living in small $20 \mathrm{~m}^{2}$ prefabricated $1 / 2$ flats in city centers comprising a bathroom and a small dining/sitting room (Nagakin Capsule Tower style) with a ceiling height of $2.1 \mathrm{~m}$ (almost the height of a man) who continually eat from outside. ${ }^{79}$ Baudrillard, as one of the philosophers adept in describing the simulative transformation process, puts forth as an example a man eating alone in the heart of central New York who no longer conceals himself as he eats leftovers in public, naming this urban and industrial poverty. ${ }^{80}$ Baudrillard talks about "the desertified postcatastrophe world where thousands of lone men, each running to their own account, with no thought for others, with a stereophonic fluid in their heads that oozes through into their eyes where the natural universe is lost and where uncertainty and modern simulation reach their peak amidst a culture that is everything and nothing at the same time." According to him, there is a lack of dizzying excitement and character as much as a lack of architecture in modern constructed cities. Cities that belong to no one have transformed into satellites of shopping centers. ${ }^{81}$ The death of the uniformist modern city has been through factories as negative satellites. The communal has been

\footnotetext{
78 Andrew Price, "The Living City vs. The Mechanical City," accessed September 9, 2018, https://www.strongtowns.org/journal/2018/5/1/the-living-city-vs-themechanical-city.

79 "Living in the Hyperreal Post-modern City."

80 Baudrillard, The Consumer Society, 52.

81 Baudrillard, Simulacra and Simulation, 77.
} 
absorbed and engulfed in cities as the centers of capital, leaving no traces of mutual sensuality or responsibilities for the past and the future. There are only masses with deceptive physical appearances in cities where 9/10 of people are the virtual dead or ghosts.

According to Sorgner, technology can be actualized in various styles and appearances as genetic, morphologic (e.g., plastic surgery), pharmacologic or cyber-technologic (creating mechanical or digital cyborgs, through digital entity development, and by means of uploading the content of the mind of an individual to the computer). ${ }^{82}$ It is almost as if cyborg people and cities render the dualist human understanding of Cartesian philosophy uniformist. The idea of cyborg urbanization supports the modern city as a style of body-technology conceptualization. In addition, it explores the privileges of digital or virtual reality on material spaces. In this regard, the evolution and advancement of the body-technology-space context is the political project of resistance and accumulation. The cyborg as a spatial concept is the experience of both the real and the virtual. Post-industrial growth and development extend to the cities. Urban infrastructure transforms into a system serving cybernetic investments as a hybrid/crossbreed of machines and organisms and as anthropic life support systems. Cyborg cities (relationships between bodies, technologies, and spaces) are shaped through advancements in wireless and mobile communication technologies.

Urban management professionals make use of novel communication systems (mobile phones, tablets, etc.) rather than computerization and simple tools of communication. Mobile compatible, or, in other words, the digitalizing city, is neither political-industrial nor corporate-imaginary; it is now a cyborg city where the digital and rational mind-space intersects and is objectified. A new style of political and social life has developed with the emergence of cyborg cities and cyborg citizens. Means of informatics, information, communication, and transportation have led to the emergence of new forms of communities with significant comfort and democratic participation. The new epistemology of knowing and understanding propound a political integrity with the cyborg city. Humans, as the conceptual explanation of ontological and

82 Dağ, Transhümanizm: Insanın ve Dünyanın Dönüşümü (Istanbul: Elis Yayınlar1, 2018), 149. 
epistemological crossbreeds, examine the cyborg as a criticism of geography. Cyborg is a simultaneous being/becoming and knowing/ seeing conduit. Cyborg human is a being that carries out the border wars between the natural and the virtual and that involves the combination of imagination and reality. The cyborg identified by Haraway as ready and waiting, invisible can be utopian and dystopian. Cyborg cities interact with bifurcated urban geographies thereby establishing interactions with social polarization and wider lands. ${ }^{83}$

While the living individual experiences the process of cyborgification through sophisticated and digital communication networks (smart phones, tablets, and social sharing websites), he/she will also transform the space in which he/she lives into a smart, digital or cyborg space. The city has required a settlement to be integrated with human systems equipped with technological and digital physical elements to ensure the compliance of its citizens with the technological and the digital world. Technology is used in the design and functioning of the infrastructure and design of smart buildings built in this context, designed to meet the current and future needs of their citizens. There should be more than just benefiting from technology in smart cities; governance and growth, urban development and infrastructure, environment and natural resources make it necessary to take into consideration society and its expectations. The smart city approach pays attention to infrastructure, transportation, governance, work, economy, and land use planning. It aims to solve, by way of digital installations, the problems of the city, from regional to individual projects. It creates more opportunities for efficiency by utilizing the benefits of technology. ${ }^{84}$ New cities materialize as cyborg cities with their sociopolitical, technical, physical, and digital infrastructures. Cyborg discussions (smart networks, smart meters, public Wi-Fi, wide area connections, and big data) with changing human technology shape the relationship between time and space together with the mutual political and industrial common spaces along with the boundaries between the social and technical. ${ }^{85}$

\footnotetext{
83 Steele et al., "The Cyborg City," 2-5.

84 "Designing Smart Cities."

85 Steele et al., "The Cyborg City,"1.
} 
Digital or smart cities built on the plane of technology-humanspace encompass financial and political projects with regard to their potentials. Mechanical cities have been built during the industrialization period, whereas virtual cities (Dubai, Las Vegas) have been built in the age of advanced technology. Advancements of digital and cybernetic technology are interventions for building digital or smart cities. The Xiong'an New Area, which China considered building as the second capital, is one of the first examples of a blockchain city. China and India are working on sustainable cities, whereas Cambodia and Vietnam, considered $4^{\text {th }}$ world economies, are working on building new complex construction. There are many Middle Eastern cities that emerge as the prototype of future global cities. Masdar, as an example of a sustainable city in the UAE, is ecologically the smart city of the future. The King Abdullah economic city in KSA (Kingdom of Saudi Arabia), the Qatar Knowledge City and Khabary Future in Qatar, and al-Irfan in Oman are among various examples for the urban age. Modderfontein in South Africa, Hope City in Accra, and Eko Atlantic in Nigeria are among the various examples of cities that emerge as the new face of Urban Africa. ${ }^{86}$

According to Baudrillard, the object that does not have a reality of its own is passive and may be the subject of design. This idea is not only at the theoretical level with designers, urban planners, and environmental organizers witnessing the objectivity that is dwindling day by day. It is becoming increasingly difficult to understand and explain the functions of shapes and objects. ${ }^{87}$ In this context, Baudrillard indicates that large urban areas developing in an unplanned manner have been captured during the last two decades mostly by artists and the bourgeoisie, who have changed the life and appearance of neighborhoods. According to him, this situation leads to a negative-ironic question: "Now, is this rehabilitation or a mutation?" He suggests that we witness the changes in cities as entities that move in time, which in the end acquire some sort of singularity as well as the erosion of their character. ${ }^{88}$

\footnotetext{
86 Ibid., 2.

87 Baudrillard, For a Critique of the Political Economy of the Sign, 196.

88 Baudrillard, The Singular Objects of Architecture, 44-46.
} 


\section{Conclusion}

The spaces that people live in are transformed subject to the period of time in which they live. More than half of the human population is living in cities following the rapid increase in the global population during the $21^{\text {st }}$ century, and it is probable that the ratio of people living in cities will exceed $70 \%$ during the second half of this century. Technological developments, an increasing number of companies, climate change, and migrations have changed the position of madinahs. Smart cities are being constructed in cities for a fast and comfortable way of life despite the population density and other adverse conditions. It does not seem possible to escape from the new digital technologies that are invading our madinahs, homes, and workplaces. Technologies that transform human nature and the material environment may lead to the development of utopian and dystopian cities. The continuous sophistication of technology has led to uncertainties regarding whether it will drag humanity to the brink of salvation or disaster. Madinahs have now become something other than madinahs as a result of homogenization by way of mechanical and virtual processes, leading to the construction of cloned cities. Identical buildings, districts, and streets have been constructed as a result of this homogenization, repetition, and cloning. Liquidating the historical and symbolic madinahs is putting an end to the madinah. According to the philosopher who considers the unstoppable modern architecture as a monster, architecture acting in accordance with its economic structure has nothing to do. Efforts such as ecocommunities or eco-architecture have increasingly led to an environment that resembles the hellish atmosphere of the Roman Empire. $^{89}$

City administrators and governments are acting like diseases that spread all over the body, draining the organs one by one, directing the city they live in together with other people, their sceneries and even the anger they feel towards their enemies and all that belong to them towards themselves. Wiping out history and cultural heritage has transformed into an enjoyable discovery. There is an air of disregard towards the destruction of history and architectural heritage as well as insensibility related to the construction of structures affixed right next to these spaces.

89 Baudrillard, America, 17. 
The mechanical-virtual-digital process that the madinahs went through in the West is also affecting the Turkish-Islamic madinahs. Of course, we are living a caricature version of these processes. While madinnahs such as Ankara, Istanbul and Izmir are urbanizing through slums during the industrialization process, virtualization also occurred during the 1990s with the construction of illuminated cities. It is uncertain what will become of these madinahs during the digital process. The madinahs that try to differentiate themselves and become a brand (!) through financial and bureaucratic expectations believe that transforming their physical appearance is the way to become centers of attraction. However, these efforts play on their own nature, transforming them into victims of an ever-changing aesthetic that is becoming increasingly inextricable for people. The madinahs that once played a role in our tamaddun are transforming into centerless and rootless cities as they lose their very essence.

When the architectural and social structuring ongoing since the Republic period is examined, it can be observed that the architectural and social horizon of the Ottoman era has been lost. A transformation has taken place from the aesthetic and historical architecture of the mosques to "apartment mosque" architecture, from the bedesten and imarethanes to giant monstrosities of shopping centers that leave no space for people, from caravanserais as locations of service to hotels that objectify and sanctify luxury, from madrasahs uniting the land and the sky to prisonlike schools, from the privacy and spirituality of homes with their courtyards to giant residential blocks that give birth to loneliness. We have transformed from a generation building caravanserais to serve people into one that robs people, claiming to have them live in luxury and comfort and building madrasahs uniting the land and the sky to schools resembling prisons.

We have shifted from homes that give heed to privacy and spirituality to heaps of apartments that squeeze a neighborhood or even a village into a single block, from noble and modest estates to villas that objectify luxury and extravagance. In short, the current examples of zoning and construction can in no way be the horizon or extension of the original temeddun. The current architectural approach is in no way related to the consciousness of temeddun or social memory. 


\section{DISCLOSURE STATEMENT}

No potential conflict of interest was reported by the author.

\section{BIBLIOGRAPHY}

Anık, Mehmet. "Aykırı Bir Düşünür Olarak J. Baudrillard ve Gösteriş Amaçlı Tüketim." Uluslararası Sosyal Araştırmalar Dergisi 9, no. 47 (2016): 441-453. http://dx.doi.org/10.17719/jisr.2016.1391.

Baudelaire, Charles. Modern Hayatın Ressamı. Translated by Ali Berktay. Istanbul: İletişim Yayınları, 2004.

Baudrillard, Jean. The Mirror of Production. Translated by Mark Poster. St. Louis, MO: Telos Press, 1975.

- For a Critique of the Political Economy of the Sign. Translated by Charles Levin. St. Louis, MO: Telos Press, 1981.

—. America. Translated by Chris Turner. London \& New York, NY: Verso Publications, 1989.

- Simulacra and Simulation. Translated by Sheila Faria Glaser. Ann Arbor, MI: The University of Michigan Press, 1994.

- The Transparency of Evil: Essays on Extreme Phenomena. Translated by James Benedict. London: Verso Publications, 1995. https://doi.org/10.2307 $/ 432045$.

- The Consumer Society: Myths \& Structures. London: SAGE Publications, 1998. https://doi.org/10.4135/9781526401502.

Cool Anılar I-II: 1980-1990. Translated by Yaşar Avunç. Istanbul: Ayrınt1 Yayınları, 2002.

—. Imkânsız Takas. Translated by Ayşegül Sönmezay. Istanbul: Ayrıntı Yayınları, 2005.

- Symbolic Exchange and Death. Translated by Iain Hamilton Grant. London: SAGE Publications, 2017.

Baudrillard, Jean and Jean Nouvel. The Singular Objects of Architecture. Translated by Robert Bononno. Minneapolis: University of Minnesota Press, 2002.

Bergen, Lütfi. "Medeniyetin Cüzü: Mahalle." İdeal Kent 2 (2010): 140-168.

—. Evlerimizi Kaybediyoruz: Yerlilik Meselemiz. Ankara: MGV Yayınları, 2016.

—. Kenti Durduran Şehir. Ankara: MGV Yayınları, 2016.

—. Sehir Sünnettir. Ankara: Hitabevi Yayınları, 2016.

Can, Yılmaz. "H.I-III./M.VII-IX. Y.Y. İslâm Şehri." Ondokuz Mayıs Üniversitesi Ilâhiyat Fakültesi Dergisi 6 (1992): 109-138.

Cansever, Turgut. "İslam Mimarîsi Üzerine Düşünceler." Divan: Illmî Araştırmalar 1, no. 1 (1996): 119-146. 
İslâm'da Şebir ve Mimari. 11 ${ }^{\text {th }}$ ed. Istanbul: Timaş Yayınları, 2016.

Dağ, Ahmet. Ölümcül Şiddet: Baudrillard'm Düşüncesi. Istanbul: Külliyat Yayınları, 2011.

_ Transhümanizm: Insanın ve Dünyanın Dönüşümü. Istanbul: Elis Yayınlar1, 2018.

Datta, Ayona and Abdul Shaban. Mega-Urbanization in the Global South: Fast Cities and New Urban Utopias of the Postcolonial State. London \& New York: Routledge, 2017.

“Designing Smart Cities.” Accessed August 15, 2018. https://www .designingbuildings.co.uk/wiki/Designing_smart_cities.

Gane, Mike. Baudrillard's Bestiary: Baudrillard and Culture. London \& New York: Routledge, 2003. https://doi.org/10.4324/9780203415856.

Lane, Richard J. Jean Baudrillard. London: Routledge, 2000. https://doi.org/10.4135 19781446262313.

Lefebvre, Henri. Everyday Life in the Modern World. Translated by Sacha Rabinovitch. New York: Harper \& Row Publishers, 1971.

"Living in the Hyperreal Post-modern City." https://www.designingbuildings .co.uk/wiki/Living_in_the_hyperreal_post-modern_city. Accessed January 30, 2020.

Price, Andrew. "The Living City vs. The Mechanical City." Accessed September 9, 2018. https://www.strongtowns.org/journal/2018/5/1/the-living-city-vs-themechanical-city.

Proto, Francesco. "Architecture." In The Baudrillard's Dictionary, edited by Richard G. Smith, 17-20. Edinburgh: Edinburgh University Press, 2010.

Raymond, André. "The Spatial Organization of the City." In The City in the Islamic World, edited by Salma Khadra Jayyusi, Renata Holod, Attilio Petruccioli, and André Raymond, 47-70. Leiden \& Boston: Brill, 2008. https://doi.org/10.1163 /ej.9789004162402.i-1500.15.

Spengler, Oswald. The Decline of the West Vol. I: Form and Actuality. Translated by Charles Francis Atkinson. London: George Allen \& Unwin Ltd., 1929.

Steele, Wendy, Ian McShane, Crystal Legacy, Yolande Strengers, John Handmer, and Sarah Pink. "The Cyborg City: Re-Thinking Urban Resilience through Mobile Communications." In Proceedings of the SOAC 7 - State of Australian Cities Conference (SOAC 2015), edited by Paul Burton and Heather Shearer, 1-7. Southport: Griffith University, 2016.

Tunalı, İsmail. Tasarım Felsefesi: Tasarm Modelleri ve Endüstri Tasarmm. $4^{\text {th }}$ ed. Istanbul: YEM Yayınları, 2012. 